\title{
Romantyczny intelektualizm w Dzienniku nieciagtym Zygmunta Lubicz-Zaleskiego
}

\section{Romantic Intellectualism in Dziennik nieciagty by Zygmunt Lubicz-Zaleski}

Abstract: This study attempts to depict the complicated image of Zygmunt Lubicz-Zaleski (1882-1967) as an intellectual writer, whose spiritual formation suggest both the innovativeness of ideas and their intriguing anachronism. The intellectualism of the author of Relikwiarz buchenwaldzki spans in a very baffling way the space between Romantic and neo-Romantic influences and the modernist movement; this is manifested with full force by his Dziennik nieciagty set down in the years 1904-1925, partly as a dream and experience journal - inspired by the ideas of Andrzej Towiański, Adam Mickiewicz, the 'genesis' period of Juliusz Słowacki, and works of Zygmunt Krasiński - that was also an unparalleled diary of civic virtue. The most suggestive depiction of this is found in the preface to Dziennik (that was added only in 1967), where Lubicz-Zaleski - while discussing the question of his own diaristic style - performs a criticism of 'Proustism' from a clearly egocentric, 'Rousseaian' standpoint.

Keywords: Zygmunt Lubicz-Zaleski, Dziennik nieciagty, Romanticism, Modernism, intellectualism

Streszczenie: Celem studium jest nakreślenie skomplikowanego wizerunku Zygmunta Lubicz-Zaleskiego (1882-1967) jako pisarza intelektualnego, którego formacja wewnętrzna sugeruje zarówno prekursorstwo myśli, jak i ich interesującą anachroniczność. Intelektualizm autora Relikwiarza buchenwaldzkiego zawieszony został w niezwykle frapujący sposób w przestrzeni pomiędzy romantycznymi i neoromantycznymi wpływami oraz modernistyczną formacją, co z całą siłą ujawnia jego Dziennik nieciagty spisywany w latach 1904-1925, między innymi jako dziennik snów i wrażeń inspirowany towianizmem, Adamem Mickiewiczem, Juliuszem Słowackim z jego filozofią genezyjską i Zygmuntem Krasińskim, a zarazem - jako wybitny diariusz postawy obywatelskiej. Nader wymowne pod tym względem pozostaje w Dzienniku... Stowo od autora (stworzone dopiero w $1967 \mathrm{roku}$ ), w którym Lubicz-Zaleski, rozpatrując problem własnego stylu dziennikowego, dokonuje krytyki „proustyzmu” z wyraźnie egocentrycznego, russoizującego stanowiska.

Słowa kluczowe: Zygmunt Lubicz-Zaleski, Dziennik nieciagty, romantyzm, modernizm, intelektualizm 


\section{Wstęp}

Zygmunt Lubicz-Zaleski (1882-1967), w oczach swoich współczesnych uchodzący za mecenasa kontaktów polsko-francuskich w pierwszej połowie XX wie$\mathrm{ku}$, historyk literatury, poeta, a także dramaturg, publicysta i dyplomata polityczny - dzisiaj pozostaje figurą bez mała dla polskiej kultury zapomnianą. Nie zmienił niestety tego stanu rzeczy rzetelnie opracowany przez Jana Zielińskiego i opatrzony jego posłowiem Relikwiarz buchenwaldzki ${ }^{1}$, tom wierszy autora stworzony przezeń w niemieckim obozie koncentracyjnym, określony niedawno przez Magdalenę Izabellę Sachę specyficzną kolekcją „skrawków, notatek, drobiazgów, relikwii”' a co do ważnego dokumentu Rafaela Lewandowskiego o życiu pisarza oraz polskiego męża stanu pt. $Z$ dala od orkiestry trudno jeszcze wyrokować, czy wpłynie on na wzrost zainteresowania skomplikowaną, aktywną w wielu obszarach, lecz stale przez całe życie korzystającą z medium literatury - osobą Lubicz-Zaleskiego ${ }^{3}$.

Celem niniejszego studium jest ukazanie głębi owego literackiego medium przez dwuznaczne odwołanie do kanonów romantycznego intelektualizmu obecnych w Dzienniku nieciagtym pisanym przez Lubicz-Zaleskiego od dwudziestego drugiego do czterdziestego trzeciego roku życia. Odwołanie to dwuznaczne, gdyż przez jaskrawe odniesienia do idei romantycznych autor Dziennika sygnalizuje swoją już modernistyczną (jakkolwiek kamuflowana) przynależność. W młodości członek Związku Młodzieży Polskiej „Zet”, w wieku trzydziestu pięciu lat z kolei uczestnik prac Komitetu Narodowego Polskiego we Francji, a następnie zastępca kierownika Biura Prasowego Delegacji Polskiej na Konferencję Pokojową w Wersalu, ostatecznie - w wieku pięćdziesięciu dwóch lat założyciel oraz dyrektor Liceum Polskiego im. Cypriana Norwida w Villard-de-Lans, zatem - jedynej wolnej szkoły polskiej na terenie okupowanej Europy: w każdym z tych okresów Lubicz-Zaleski pozostawał aktywny literacko, a nierzadko też - naukowo i publicystycznie.

Zadebiutowal jako poeta w 1914 roku tomem Na waskiej miedzy snu i bu$r z y$, lecz już wtedy pozostawał znany jako interpretator polskich romantyków i autor prekursorskich studiów literackich Dzieto i twórca. Studia i wrażenia literackie. Owszem, współpracował przez lata z „Mercure de France” (19201935), a także (w krótszym okresie 1925-1928) z wydawanym od 1831 roku „Le Messager Polonais”, jednak przez cały ten czas pisał oraz wydawał, między innymi w 1932 roku swój dramat Geniusz z urojenia, po wojnie zaś estetyzujące prozy poetyckie - Akordy kamienne z 1946 roku oraz Kariatydy stracone z 1948

${ }^{1}$ Z. Lubicz-Zaleski, Relikwiarz buchenwaldzki, oprac., posł. J. Zieliński, Warszawa 2016.

2 M.I. Sacha, Skrawki, notatki, drobiazgi, relikwie. O poezji buchenwaldzkiej Zygmunta Lubicz-Zaleskiego, „Acta Universitatis Lodziensis. Folia Litteraria Polonica” 2018, nr 1, s. 17-39.

${ }^{3} Z$ dala od orkiestry, reż. R. Lewandowski, Polska 2017, 86 minut. 
roku. O tych wydaniach nie powinno się zapominać, podobnie jak o Dzienniku nieciagtym - będącym formą stylizowanego, inicjacyjnego pseudodokumentu, którego wartości literackie w dużym stopniu posłużyły Zaleskiemu (jako polsko-francuskiemu homo duplex) w jego fundamentalnej, podwójnej (auto-?) rewizji polskiej kultury romantycznej i polskiej kultury romantyzmu w ogóle ${ }^{4}$.

\section{Romantyczne wpływy, modernistyczna formacja?}

Wpływ polskich lektur romantycznych na Zygmunta Lubicz-Zaleskiego miał charakter długofalowy i formacyjny. Jeżeli mówić o pełnej skali ich rezonansu, uwydatnia ją z pewnością jego twórczość literacka, a wraz z twórczością - pisma literaturoznawcze i wystąpienia o charakterze historyczno- i krytycznoliterackim. W pięciu pierwszych numerach pisma „Znicz”, z którym współpracował w 1904 i 1905 roku Zaleski ogłosił dramat Zżycia studentów warszawskich. Jeszcze przebywając w Polsce (do 1910 roku), napisał oraz opublikował na łamach „Przeglądu Naukowego” szkic Kobieta i kobiecość w poezji Juliusza Stowackiego. W 1911 i 1912 roku powstała z kolei ważna, chociaż okolicznościowa broszura o Zygmuncie Krasińskim, zatytułowana: Zygmunt Krasiński. O dziele $i$ życiu poety $w$ setna rocznice urodzin. Zygmunt Lubicz-Zaleski miał wówczas trzydzieści lat. Honorował u autora Irydiona wówczas przede wszystkim dojrzałą mesjanistycznie oraz ideowo wyrafinowaną twórczość lat czterdziestych:

W Trzech myślach, w Przedświcie, w Psalmach przysztości - głosząc myśli pokrewne objawieniom Mickiewicza i widzeniom Słowackiego - najpełniej, najjaśniej i najgłębiej, choć nie najmocniej ani najpiękniej wypowiedział Krasiński wiarę w posłannictwo i wielkość Polski5.

Nie sposób nie wspomnieć w tych okolicznościach o obszernym tomie studiów wydanym przez Zaleskiego przed pierwszą wojną światową, czyli - o szkicach literackich i rozważaniach teoretycznych z ważnego i reprezentatywnego dla autora zbioru pt. Dzieto i twórca. Pisał tam między innymi Zaleski o francuskim symbolizmie, poecie Albercie Samainie oraz Alfredzie Jarrym, o francuskim historyku literatury, komparatyście, Fernandzie Baldenspergerze, do tego również o wybitnym reprezentancie filozofii idealizmu kultury Benedetcie Crocem. Należy podkreślić z całą mocą, że horyzont zaproponowany w Dziele i twórcy nie został nigdy przez jego autora „uchylony”. Stanowit,

${ }^{4}$ Zob. więcej na ten temat: M. Willaume, Wstęp [w:] Z. Lubicz-Zaleski, Dziennik nieciagty (1904-1925), oprac., przyp. M. Willaume, Paryż-Łódź 1998, s. 5-16.

${ }^{5}$ Z. Lubicz-Zaleski, Zygmunt Krasiński. $O$ dziele i życiu poety $w$ setna rocznicę urodzin, Warszawa 1912, s. 71. 
jeśli nie do końca, to przynajmniej w latach pisania przez Zaleskiego Dziennika nieciagtego (1904-1925), podstawowy filtr jego recepcji, a także animacji w środowisku kulturalno-emigracyjnym i poza nim (w Paryżu, w którym przebywał od 1913 roku) podstawowych idei polskiego romantyzmu. Intelektualizm romantyczny - to modernistyczny model czytania Adama Mickiewicza, Juliusza Słowackiego, Zygmunta Krasińskiego et consortes, który Zalewski przedstawił na emigracji zarówno Polakom, jak i Francuzom z Polakami sympatyzującym.

Już w 1913 roku zaproponowano mu wygłoszenie kilku wykładów przed audytorium francuskim - razem z Paulem Cazinem oraz Georges'em Bienaimé. Mówił o pierwszym „powiewie" mistycznego romantyzmu, czyli o poezji emigrantów (1830-1850), a także - ze swojej genetycznej perspektywy - o renesansie romantyzmu i nowej orientacji literackiej w latach 1880-1905. Od 1914 do 1916 roku Zaleski wykładał język polski w École des Hautes Études Sociales. W 1916 otrzymał propozycję wykładów o języku polskim w École des Langues Orientales et Vivantes.

W dwóch pierwszych dziesięcioleciach XIX wieku wiele pisał o związkach literackich, politycznych i duchowych pomiędzy Adamem Mickiewiczem, Jules'em Micheletem oraz Edgarem Quinetem, między innymi do „Mercure de France” (1920-1935), a także do „Le Messager Polonais” (1925-1928) w Warszawie. Józefa Piłsudskiego miał z kolei określać w 1921 roku „najwierniejszym synem polskiego romantyzmu"'. Na te lata - od roku 1904 do 1925 datowany jest tak zwany Dziennik nieciagty, będący dokumentem zarówno romantycznego-inicjacyjnego wejścia w dorosłość, jak i kształtowania się „obywatelskiego intelektualizmu” Lubicz-Zaleskiego, całkowicie oraz wyłącznie niemal opartego na kanonie myśli intelektualnej polskiego romantyzmu. W niniejszym studium to Dziennik nieciagty będzie przedmiotem fundamentalnych rozpoznań w dziedzinie romantycznego światopoglądu intelektualnego - takiego, jakim dysponował założyciel oraz pierwszy dyrektor Liceum Polskiego im. Cypriana

${ }^{6}$ Za: L. Talko, Przedmowa [w:] Z. Lubicz-Zaleski, Dziennik nieciagty (1904-1925), dz. cyt., s. 3. Ignacego Paderewskiego odczytywał z kolei Lubicz-Zaleski jako „późnego wnuka” i niemal ostatniego dziedzica romantycznej szkoły ukraińskiej. Pisał o nim w związku z jego śmiercią 25 lipca 1941 roku. Rysował też wówczas głęboki, psychologiczny portret zmarłego i - co znamienne, szokujące - podkreślał nie tylko „stepowość”, lecz także niejaki „bowaryzm” autora Fantazji polskiej. Uzyskiwał w ten sposób nader specyficzny, modernistyczny portret nekrologowy, dyskretnie zapośredniczony skądinąd w duchu oraz stylu Czarnych kwiatów Norwida: „w czasie mojej grypy umarł Paderewski... Podśmiewałem się kiedyś z jego słabostek i z jego, powiedziałbym, bowarystycznych wylań... Dziś, patrząc z oddali, muszę przyznać, iż był to przede wszystkim człowiek piękny. Jego gest był zawsze gestem Polski. Nie tylko Wielkopolski, jakby ktoś mógł sądzić... Przeciwnie. W geście Paderewskiego wypowiadającym całą Polskę pobrzmiewał mocniej akcent kresowy. Bogactwo tego impetu duszy polskiej, który szedł ku otwartym na ścieżaj stepom Ukrainy...”. Z. Lubicz-Zaleski, Vichy, 25 VII 1941 [w:] tegoż, Pamiętnik. Od Grotowic do Buchenwaldu (1939-1945), oprac., przyp. M. Willaume, Paryż-Łódź 1998, s. 112. 
Norwida w Villard-de-Lans ${ }^{7}$. Należałoby w tym wypadku powrócić także do pytania o „romantyczny”, a wręcz „ultraromantyczny modernizm” Lubicz-Zaleskiego. Czy jest to nota bene w ogóle modernizm? Czy mógłby on w istocie zaistnieć - tak silnie oparty na wątkach tradycjonalistycznych, czerpiąc siłę de facto jedynie z ich twórczego, regeneracyjnego przetworzenia?

\section{Patronat Rousseau}

Niezwykle frapująca okazuje się pod tym względem ocena Dziennika nieciagtego dokonana przez Lubicz-Zaleskiego z perspektywy czasu. Autor ma szansę ją wyartykułować dokładnie w roku śmierci, to jest w 1967. Stworzone wówczas Stowo od autora jest symptomatyczne, zwłaszcza w aspekcie okoliczności jego powstania - po pierwsze, nie ma w sobie sentymentalizmu właściwego między innymi poetykom senilnym, które opisywała Teresa Kostkiewiczowa ${ }^{8}$, po drugie, jest zadziwiająco deklaratywne, nie tylko gdy weźmie się pod uwagę długi wiek życia Lubicz-Zaleskiego (osiemdziesiąt pięć lat), lecz także stan erudycji i samoświadomości, po trzecie - przede wszystkim to właśnie z perspektywy pisanego w tym wieku Stowa od autora (a więc niejako ex post i post factum naraz) można uznać cały Dziennik nieciagly za specyficzny manifest modernistycznego autobiografizmu. Autobiografizmu, dodajmy, w którym podstawowymi składowymi okazują się „prze-tworzony” oraz nowocześnie „prze-myślany” romantyzm, a także postromantyzm i neoromantyzm.

W passusie Od autora Zaleski skupia się na własnej filozofii procesu twórczego, analizując ją w duchu Henriego Bergsona i innych filozofów życia. Wyraźnie wskazuje również na swoje anty-Proustowskie nastawienie w pisaniu. Stając na stanowisku przeciwstawnym do Proustowskiej ars poetica, formułuje cały problemat i tłumaczy:

Proustyzm czyha i jakże często prowadzi na manowce! W każdym razie powstaje mimowolny dialog dwóch oświetleń: współczesnej chwili pisania i tego, które towarzyszyło ongi wydarzeniu, a dziś tak nieraz trudnego do uchwycenia - w barwie właściwej. Ta dwoistość zabarwień obrazów dalekich, ponownie przeżywanych jest cechą pamiętnikarstwa i powodem nieustannego, kontrapunktycznego przepływu ciągu wydarzeń minionych?

7 W sprawie Villard-de-Lans zob. więcej: Notre école. Mémoires du lycée polonais Cyprian Norwid 1940-1946, Villard-de-Lans 2017.

${ }^{8}$ T. Kostkiewiczowa, „Wiersze późne” jako kategoria historycznoliteracka (zarys problemu) [w:] Wobec romantyzmu. Studia i szkice ofiarowane Profesor Danucie Zamacinskiej-Paluchowskiej, red. M. Łukaszuk, M. Maciejewski, Lublin 2006, s. 9-34.

9 Z. Lubicz-Zaleski, Od autora [w:] tegoż, Dziennik nieciagty (1904-1925), dz. cyt., s. 17. 
Rozwiązaniem, które „proustyzm” w pisarstwie powinno immunizować, jest zdaniem Lubicz-Zaleskiego - „wynurzenie”. Pisarz pojmuje je specyficznie, w kodzie romantycznego sentymentalizmu spod znaku oryginalnego przesłania Jeana-Jacques'a Rousseau. Nic dziwnego zatem, że słowa, którymi Rousseau zapoczątkowuje swoje legendarne Wyznania - „czuję serce i znam ludzi. Śmiem twierdzić, że nie jestem podobny do żadnego z istniejących" ${ }^{10}$ - wracają w dalszych partiach Stowa od autora w charakterze (wcale chyba nie tak odległego) parafrastycznego echa. Właściwym, wyjściowym układem odniesienia okazuje się w Dzienniku nieciagtym russoizm pojęty jako romantyczny egocentryzm, oczywiście unowocześniony i ukształtowany w pozycji „odrestaurowanego argumentu” wyprowadzanego „przeciwko Proustowi”. Odnowiony russoizm jako remedium na zbanalizowany proustyzm - tak przynajmniej wygląda to z perspektywy roku 1967 oraz (wcale nie bagatela) osiemdziesięciu pięciu lat autora Dziennika:

Jak wybrnąć z kłopotu? Moim szczerym zdaniem - wynurzeniem. Najlepiej będzie, pisząc zwłaszcza pamiętnik, przyjąć z całą świadomością jako afirmowaną zasadę to zjawisko nie do uniknięcia: przyjąć jako punkt centralny - bez wyrzutów i zawstydzeń - osobowość własną jako oś opowieści, nie kryć się za parawanik obiektywizmu, być sobą. Punkt osi rzędnych, z którego mierzymy wszystkie dystanse. Takie bezwstydne przyznanie się do roli deformującej osobowości piszącego - mniej mącić będzie widzenie czytelnika niż hipokryzja obiektywizmu czy nieosiągalnej ścisłości fotograficznej, czy całkowitego usunięcia za kulisy sprawy uczuć... opisującej czy wspominając osobność autora pamiętnika ${ }^{11}$.

„Egocentryzm pamiętnikarza wzbogaca o cały czwarty wymiar życia widzącego i czującego obserwatora" ${ }^{12}$ - przyznaje gdzie indziej w swoim odautorskim passusie stojący nad grobem Lubicz-Zaleski. W świetle tego rodzaju zeznań (nawet jeśli przyjąć osłabiającą tezę, że są one pisane czterdzieści dwa lata po postawieniu przez autora ostatniej kropki w dziele) dużo łatwiej jest dostrzec w Dzienniku nieciagtym literacki dokument procesów twórczych oraz estetyczno-światopoglądowych autora poetyckiego zbioru Relikwiarz buchenwaldzki. To nie tylko świadectwo artystyczne możliwości twórczych, lecz także zapis zmagań artystycznych i ekspozycja twórczego stanowiska Lubicz-Zaleskiego - przeciw Proustowi, a w duchu znanych filozofii życia, szczególnie bergsonizmu, a nawet nietzscheanizmu, tą drogą natomiast - w całkowitej zgodzie z wykładnią romantyzmu egocentrycznego spod znaku Wyznań Jeana-Jacques'a Rousseau.

${ }^{10}$ J.J. Rousseau, Wyznania, wstęp, oprac. E. Rzadkowska, tłum. T. Żeleński (Boy), Wroclaw 1978, s. 3 .

${ }^{11}$ Z. Lubicz-Zaleski, Od autora, dz. cyt., s. 18.

12 Tamże. 


\section{Romantyczny rejestr snów}

Dziennik nieciagty to w znacznym stopniu również dziennik snów i widzeń. Lubicz-Zaleski w sposób bliski mistrzowskiemu potrafi posługiwać się oniryczną fantasmagorią. 28 czerwca 1915 roku notuje: „Ciągle miewam korowody snów. Ciekawy był sen - rozmowa z marmurowymi posągami. Widzę pod chustą dziecko, ale przy dotknięciu zmienia się w ptaka o zamokłym trochę pierzu - skończyłem Bergsona, Matière et memoire (Materia i pamięc)"13. Nietypowa fabuła snu może przypominać słynny, Mickiewiczowski wiersz Śnita się zima, a w nim postać Ewy: „Ona mi rzekła z uśmiechem dziecięcia:/ „Rodzice moi chcą mię z innym swatać,/ Lecz ja, jaskółka, chcę daleko latać;/ Mam skrzydła dobre, patrz, jaki ptak ze mnie!/ Lecę popłukać pióra moje w Niemnie "14. Frapuje tu oczywiście Bergson jako koda i specyficzny punkt dojścia dziwnego snu Zaleskiego. Może być znakiem gry (choćby i półświadomej), jaką z konwencją dziennika snów i widzeń prowadzi (mimowolnie?) Zaleski, zacierając przestrzenie snu oraz prywatnej, filozoficznej lektury.

Sen - jak domniemywaliśmy na podstawie sytuacji lirycznej Mickiewiczowskiego utworu Śnita się zima - to bynajmniej nie wyjątek w ukrytej w Dzienniku nieciagtym „księdze snów” Lubicz-Zaleskiego. 5 grudnia 1916 roku Zaleski odnotowuje „straszny sen o Mickiewiczu”, ale nie odważa się zdradzić jego szczegółów. Nie skąpi ich dopiero w kontekście drugiego, grudniowego snu z 1916 roku (26 grudnia):

Moje sny. Jeden zapomniany prawie, dawniejszy. Kościół wielki, ale znajomy jakbyniby odechowski, ale zogromniały. Otrzymuję buńczuk wielki, złocisty, a właściwie ze szczerego, czystego złota, pięknej choć nieco grubej roboty. Buńczuk ciężki, koniec jego - szczyt nieco pochylony na prawo, zgięty. Głos jakiś mówi mi, że buńczuk to jagielloński. Potem pochód jakby się rozwija, idę w pierwszym szeregu wciąż z buńczukiem owym, dalej obraz zmącony już jakichś mów, walk tłumnych..., gonitw ${ }^{15}$.

Zadziwiające, ale sceneria tu jak z Zygmunta Krasińskiego, skrzyżowanie przestrzeni Legendy z Trzech myśli pozostatych po ś.p. Henryku Ligenzie („kościoła wielkiego, ale znajomego jakby" i Bazyliki św. Piotra w Rzymie) oraz Przedświtu z wersami takimi, jak „tam buńczuki, tam sztandary, / Śnieżne pióra i korony” ${ }^{16}$, „przebóstwieni - rozzłoceni,/ Przesuwają się w przestrzeni,/ jak-

13 Z. Lubicz-Zaleski, Poniedziatek, 28 VI 1915 [w:] tegoż, Dziennik nieciagty (1904-1925), dz. cyt., s. 137.

${ }_{14}$ A. Mickiewicz, Śnita się zima [w:] tegoż, Dzieta, red. J. Krzyżanowski, t. 1: Wiersze, Warszawa 1955, s. 347-348.

${ }^{15}$ Z. Lubicz-Zaleski, 26 XII 1916 [w:] tegoż, Dziennik nieciagly (1904-1925), dz. cyt., s. 183.

${ }_{16}$ Z. Krasiński, Przedświt [w:] tegoż, Dzieta zebrane. Nowe wydanie, red. M. Strzyżewski, t. 2: Poematy, Torun 2017, s. 124. 
by znowu szli do boju” ${ }^{17}$. Jak przypomina Elżbieta Dąbrowicz, „w Legendzie do Bazyliki św. Piotra zdążał hufiec »ostatków szlachty polskiej«, »ostatnich bohaterów ziemi«, żeby dać się pogrzebać pod jej gruzami razem z papieżem: »szli w białych płaszczach i w połysku szabel«" 18 .

26 marca 1919 roku - jak skrupulatnie odnotowuje w Dzienniku - dokładnie o godzinie dwunastej w nocy Lubicz-Zaleski śni sekwencję następujących po sobie obrazów, które stanowią rodzaj przedziwnej, onirycznej syntezy Ksiag narodu polskiego i pielgrzymstwa polskiego, imaginarium genezyjskiego Słowackiego, wspomnianego już Przedświtu, a nawet Norwidowskiego Promethidio$n a$. Sen ten jest w jego pamiętniku punktem progowym - od tego momentu o wiele częściej śni sny profetyczno-mesjanistyczne niż (jak w pierwszych latach prowadzenia Dziennika) - wizyjne:

Dziś znowu sny. Jeden niesłychanie zawiły - rzé́biarski. Drzewo narodów - jakaś reminiscencja chyba sądu ostatecznego Michała Anioła z Kaplicy Sykstyńskiej. Wicher ciał ludzkich rwących wzwyż. Narody o kulturze wysokiej, prawie wszystkie gałęzie przerodziły się w ciała splątane i wyprężone, wśród nich Polska. Narody o kulturze i świadomości słabszej - wyrażają się w kształtach roślinnych przeważnie. Rzeźba w drzewie ${ }^{19}$.

O ile kontekst Mickiewiczowskich Ksiag wydaje się tutaj względnie jasny, o tyle Przedświt Krasińskiego i obraz wstąpienia w niebo polskiego rycerstwa (stabilizujący plan wertykalny snu Lubicz-Zaleskiego), Genezis z Ducha Słowackiego (kluczowa w perspektywie przywoływania „kształtów roślinnych” dla „narodów” o „słabszej świadomości”) i wreszcie Promethidion (istotny w zrozumieniu całej domniemanej „,rzeźbiarskości” snu mężczyzny) to teksty romantyczne, których impresyjną obecność należałoby bezpośrednio tutaj uzasadnić. Uczynię to za pomocą trzech cytatów:

Przewodowo - z wolna-święcie/ Przez to dźwięków rozbłyśnięcie/ Idą, idą wszystkie mary./ Patrzaj, patrzaj: w dziwnej chwale,/ Wszyscy z trumien polskich rodem,/ Idą - idą przez te fale/ Chrystusowym do nas chodem! (...) Już ich tknęło światło boże/ I gdzieś spieszą - zbrojnie - skoro./ Złotem wokół szklni jezioro,/ Na ich hełmach błyska zorze;/ W dawnych polskich bitew stroju,/ Przebóstwieni - rozzłoceni,/ Przesuwają się w przestrzeni,/ Jakby znowu szli do boju!/ Srebrne skrzydła, w zbroję wtknięte,/ Im znad ramion w górę lecą,/ Jak anielskie skrzydła świecą;/

17 Tamże, s. 125.

${ }^{18}$ E. Dąbrowicz, Poeta-anonim, „Sztuka Edycji” 2012, nr 3, s. 44.

19 Z. Lubicz-Zaleski, 26 III 1919, godzina 12 w nocy [w:] tegoż, Dziennik nieciagty (19041925), dz. cyt., s. 246. 
Turkusami zbroje spięte,/ Z żywej stali rękawice,/ Strusie pióra wyżej głowy/ I dobyte do połowy/ Damasceńskie ich szablice ${ }^{20}$.

Każde drzewo jest wielkim rozwiązaniem matematycznego zadania, tajemnicą liczby, która w niedokonalszych roślinach przez parzyste, w postępowych zaś przez nieparzyste iloście postępując, w drzewie całym rozwiązuje się jednością”. „Dotychczas myśl sama tworzyła w duchu roślinnym, rachowała się trzema listkami, idąc po łodydze, a pięcią tłumaczyła się w kwiecie; myśl osadziła kwiaty około jednej matki, stworzyła rodzinę i przeczucie narodowości. (...) I ty, respubliko ateńska, przebacz, że początek twój widzę w tym kwiatku koniczyny, który się składa z równych, osobnych, nie w jednym kielichu, ale na jednej łodydze trzymających się obywateli, między którymi jednak Themistokles, choć niczym nie różny od innych, siedzi na czele piramidy i zajmuje najwyższe stanowisko ${ }^{21}$.

O, gdybym jedną kaplicę zobaczył,/ Choćby jak pokój ten, wielkości takiej,/ Gdzie by się polski duch raz wytłumaczył,/ Usymbolicznił rozkwitłymi znaki,/ Gdzie by kamieniarz, cieślarz, mularz, snycerz,/ Poeta, wreszcie męczennik i rycerz/ Odpoczął w pracy, czynie i w modlitwie.../ Gdzie by czerwony marmur, cios, żelazo,/ Miedź, brąz i modrzew polski się zjednały,/ Pod postaciami, co niejedną skazą/ Poryte, leżą w nas, jak w sercu skały;/ O tobym w liściach rzeźbionych paproci,/ I w koniczyny treflach, i w stokroci,/ I w kos zacięciu łukiem, i we freskach,/ O bazylianek mówiących męczeństwie,/ $\mathrm{O}$ tobym nawet w drobnych arabeskach,/ Z naturą rzeczy polskiej w pokrewieństwie/ Nierozplątanym będących, doślepił,/ Że to miłości balsam brąz ten zlepił!22

Tak rozwinięty, osobliwy katalog snów Lubicz-Zaleskiego nie zostałby wyczerpany bez omówienia grupy koszmarów i snów makabrycznych zdradzających oddziaływanie na autora towiańczyków, poglądów Andrzeja Towiańskiego, a przede wszystkim - wypełnionego proroczymi snami i widzeniami Dziennika Sprawy Bożej Seweryna Goszczyńskiego. Czas śnienia koszmarów w drugiej połowie 1914 roku, na progu tak zwanej Wielkiej Wojny, zostaje

20 Z. Krasiński, Przedświt, dz. cyt., s. 123-124, 125. Oniryczna wizualizacja „drzewa narodów” Lubicz-Zaleskiego przypomina także wizualizacje z Pokusy, w której bohaterowi Krasińskiemu na cmentarzysku Ludów „zdawało się, że cienie umarłych pomykają przed nim, spłoszone, i jęcząc, uciekają dalej - aż zrasta się z nich tuman podobny do burzy, co chwila ogromniejszy, szumiący tysiącem smętnych pieśni rodzinnych”. „Znać było jakoby migotanie szabel i przewiew sztandarów w powietrzu". Tenże, Pokusa [w:] tegoż, Dzieta zebrane..., dz. cyt., t. 6: Proza poetycka III, s. 431.

21 J. Słowacki, Genezis z Ducha. Modlitwa [w:] tegoż, Dzieta wybrane, wyb., przedm. M. Bizan, P. Hertz, t. 1: Wiersze i poematy, Warszawa 2009, s. 457-458.

22 C. Norwid, Promethidion. Rzecz w dwóch dialogach z epilogiem [w:] tegoż, Pisma wszystkie, zebrał, tekst ustalił, wstęp i uwagi krytyczne J.W. Gomulicki, t. 3: Poematy, Warszawa 1971 , s. 444. 
zapoczątkowany okresem barbarzyńskiego bombardowania Reims. 20 września 1914 roku Zaleski lamentuje nad dewastacją katedry Najświętszej Marii Panny w Reims. Padają słowa stanowcze, a i ostre w swoim wydźwięku. Emocje biorą górę nad dotychczasowym, cyzelatorskim opanowaniem Dziennika:

Niemcy bombardują katedrę w Reims! Katedra w Reims stoi w płomieniach! Tak głosi dzisiejszy komunikat urzędowy. Moje cudowne, kochane Reims! Dusza mi się buntuje i chłód mój, z jakim patrzę, chcę patrzeć na te zapasy - pierzcha jak wicher. Łajdaki, zbiry - psiakrew! Chcą zniweczyć symbol mocy narodu, tej mocy, wytwornej mocy wcielonej w piękno, którego cud jest im obcy na wieki. Ach, prawda ich wystudzone, wymierzone, wykończone na glanc katedrzysko kolońskie! Grube, obmierzłe, nieokrzesane małpowanie! ${ }^{23}$

Skutkiem, gorzkim pokłosiem wstrząsu są sny - w 1914 roku jeszcze w większym stopniu wizyjne, niż (jak już wyraźnie w 1919 roku) profetyczno-mesjanistyczne: „znowu sny, ciągle sny i sny. Najpierw płomienisty jakiś... wysadzanie czegoś w powietrze, wybuchy kolejne, snopy iskier i miotły płomienne, tryskają wzwyż, huk i ogien'"24. Lektura snów oraz widzeń Lubicz-Zaleskiego z września, października oraz listopada 1914 roku przywołuje na myśl uderzające podobieństwa między postromantycznym oniryzmem autora dziennika a oniromancją obecną w Kole Sprawy Bożej Andrzeja Towiańskiego czy (w ogóle) religią snu w towianizmie. Podobnie także estetyka laickich objawień bliska dziełom Słowackiego genezyjskiego w pierwszych miesiącach po wybuchu wojny nie będzie od Lubicz-Zaleskiego odstępować na krok. Ostatecznie 22 września autor Dziennika nieciagtego sam sobie postawi diagnozę. Tak jak w pisanym wiele dziesiątek lat później Stowie od autora jej wydźwięk (już w 1914 roku) będzie poniekąd russoistyczny, a więc w tym wypadku romantyczno-egocentryczny:

Niesłychane bogactwo mojego życia w snach musi oddziaływać na moje życia na jawie. Czuję bowiem w snach moich jakby przedłużenie mojego życia świadomego - smugę widzialnych uczuć, nastrojów, stanów wewnętrznych. Wszystko chroni się w te podziemia, gdzie najcieńszy szmer staje się muzyką i dzwonem, a najzwiewniejszy poblask tryska z mocą fanfary słonecznej $j^{25}$.

W tym wypadku „fanfary słoneczne” odsyłać mogą do genezyjskiego mitu Jerozolimy słonecznej, której mistyczną ekspozycję zawarł Słowacki w piątym akcie Samuela Zborowskiego. Wpływ wcześniejszych dramatów poety z tego

${ }^{23}$ Z. Lubicz-Zaleski, Niedziela, 20 IX 1914 [w:] tegoż, Dziennik nieciagty (1904-1925), dz. cyt., s. 46.

${ }^{24}$ Tenże, Wtorek, 22 IX 1914 [w:] tegoż, Dziennik nieciagty (1904-1925), dz. cyt., s. 47.

25 Tamże, s. 48. 
okresu: Snu srebrnego Salomei oraz Księdza Marka dostrzec można w wymownym wpisie Lubicz-Zaleskiego z 1 listopada 1914 roku - wymownym, gdyż nie jest on jedynie zapisem snu, lecz także poprzedzającego ów sen wieczornego spotkania. Spotkanie owo to po części rodzaj emigracyjnych „dziadów”, po części jednak również zebranie na podobieństwo zgromadzenia „,siódemki” Sprawy Bożej Andrzeja Towiańskiego. Po dywagacjach o „Mickiewiczowskiej 44”26 przychodzi czas - tak jak ponad pół wieku wcześniej w sekcie towiańczyków na wzajemne, jeszcze nieoniromanckie, opowiadanie i tłumaczenie sobie snów. Zaskakuje znów Lubicz-Zaleski:

Skończyło się na opowieści o snach. Wspominałem naturalnie o moich. Sen ostatni o gwiazdach spadających pamiętam dość żywo. Jestem w dość licznym towarzystwie na wsi, noc głucha, sylwetki drzew i dumna gwiazda płomienista, o żywym błękitnym tle zatacza parabolę. Spostrzegłszy ją, mówię głośno: trzeba pomyśleć jakieś życzenie, i pomyślałem równocześnie: «zwycięstwo Koalicji i sprawy Polski niech się stanie». Wtedy gwiazda zatrzymała się nad moją głową w punkcie A1. Wówczas rzuciłem z głębi serca drugie życzenie: „niech Małgośka mnie kocha”, wówczas gwiazda zaczęła dalej spadać, a na niebie pokazały się inne znaki (twarze, potwory koloru miedzi, bardzo niejasne), których nie mogłem pochwycić wyraźnie i zapamiętać; ogarnęło mnie jednak wówczas przerażenie, groza i chłód zarazem fizyczny, w którym zamarł czy zastygł sen pełen blasków i zamętu²7.

"Gwiezdny” sen Zaleskiego ponownie przypomina fabuły genezyjskie Słowackiego, zwłaszcza Sen srebrny Salomei (spadająca i zastygająca nad głową mężczyzny gwiazda) oraz Księdza Marka (znaki, potworne twarze w powietrzu). Niech nie umknie uwadze fakt, że katastrofizm genezyjski Słowackiego ujawniający się w snach Lubicz-Zaleskiego niemal na prawach deus ex machina łączy się z określonymi wydarzeniami historycznymi preludium Wielkiej Wojny w Paryżu. Salomea Gruszczyńska śni u Słowackiego nadchodząca, makabryczną zagładę dworu w Gruszczyńcach, znaki na barskim niebie widziane z kolei przez Starościca zapowiadają katastrofę, upadek i (poniekąd,

26 „Wczoraj wieczorem był Moycho (znów powiedział mi na wstępie jakieś kazanie, że choruję przez imaginację). Później przyszedł Bańkowski. Dość interesująca gawęda. Tworzyliśmy i rozwinęliśmy nowe hipotezy interpretacji Mickiewiczowskiej 44. Bańkowski dawał ciekawą interpretację hebrajską. W języku hebrajskim podobnie jak w słowiańskim i greckim litery oznaczają także liczby. Otóż 44 napisane po hebrajsku i czytane jako słowo - oznacza podobno krew czy walkę. Znaczyłoby to, że zbawcą Polski będzie "krew « w ogóle - wojna powszechna. Śmiejąc się, powiedziałem, że nowe proroctwa gotowe. Ze swej strony [symptomatyczne, bo ewidentnie w kontrze do Bańkowskiego - K.S.] dawałem interpretację psychologiczno-estetyczną (rym - obraz - ton ogólny - tajność), negując w ogóle doniosłość wszelkiej interpretacji dialektycznej (czy kabalistycznej)". Z. Lubicz-Zaleski, Niedziela, 1 XI 1914 [w:] tegoż, Dziennik nieciagly (1904-1925), dz. cyt., s. 71.

${ }_{27}$ Tamże. 
w znaczeniu genezyjskim) ofiarę całopalną miasta. Należy spojrzeć na ten specyficzny oniryzm z perspektywy trudnej drugiej połowy roku 1914:

\section{SALOMEA:}

Ach, Boże mój!/ Dlaczego taka noc cicha!/ Dlaczego tych gwiazd taki rój?/ Dlaczego jedna, zda się, wzdycha?/ A druga leci gdzieś z daleka?/ A trzecia krwawa jak pies szczeka/ I na błękitach mi ujada;/ A czwarta - ach! a czwarta spada,/ I nad Gruszczyńcami zgasła./ Ledwie żem z trwogi nie wrzasła,/ Widząc tę gwiazdę przy zgonie/ Jak główkę ducha z oczami./ Ach! jak tam smutno w tej stronie!/ Jaka mgła nad Gruszczyńcami ${ }^{28}$.

\section{STAROŚCIC:}

Ponieśli dalej sztandary,/ Poszli dalej z bronią w ręku,/ A ta pieśń na fundum wiary,/ Anielskiego pełna jęku,/ Ściąga nam cudy, zjawienia,/ Przelotne niebios humory,/ Gwiazdy z grzywą, meteory,/ Nocne słońca, łby z płomienia,/ Szwadrony w zbrojach nieznanych,/ Po obłokach malowanych/ Idące truchtem i cwałem,/ (...)/. Więcej serca w naszem łonie,/ Bo ta wielka zawierucha/ Niebios wszystkich nas pochłonie ${ }^{29}$.

W tej sytuacji pojawienie się w zapisach snów i widzeń Lubicz-Zaleskiego klasycznej frenezji jest wyłącznie kwestią czasu. Obraz żywej makabry przynosi noc z 3 na 4 listopada 1914 roku. Czytamy już w zapisie dziennym z 4 listopada:

Znowu sen. Duże pole zaorane i zabronowane, gotowe pod siew, pole wznosi się wyraźnie i dość pochyło. Na płaszczyźnie spostrzegam coś jakby grotę kamienną. Jestem teraz sam. Wchodzę - po lewej stronie gromadka ludzi - chłopi, baby. Po prawej, w głębi, olbrzymia „ćwierć” mięsa ociekającego krwią. Wtem ktoś mówi i ja sam mam to wrażenie, że to zaczyna „być czuć” (jak mówi moja Mama). Wychodzę z pieczary, jest noc, ciernie, sterty płonące - ostatnie widzenie rozpływa się szybko $^{30}$.

Scena z okrwawioną „ćwiercią” mięsa może u Lubicz-Zaleskiego przywodzić na myśl makabryczno-wizyjne sny towiańczyków, a szczególnie pierwszy tego rodzaju sen Seweryna Goszczyńskiego z 4 czerwca 1842 roku. Ten - być może najostrzejszy z całej grupy snów autora Dziennika Sprawy Bożej-zadecydował ostatecznie o jego akcesie do sekty religijnej Andrzeja Towiańskiego.

${ }_{28}$ J. Słowacki, Sen srebrny Salomei. Romans dramatyczny w pięciu aktach [w:] tegoż, Dzieta wybrane, wyb., przedm. M. Bizan, P. Hertz, t. 3: Dramaty, część druga, Warszawa 2009, s. 133-134.

${ }^{29}$ Tenże, Ksiadz Marek. Poema dramatyczne we trzech aktach [w:] tegoż, Dzieła wybrane, t. 3, dz. cyt., s. 10-11.

${ }^{30}$ Z. Lubicz-Zaleski, Środa, 4 IX 1914 [w:] tegoż, Dziennik nieciagty (1904-1925), dz. cyt., s. 76 . 
Grota kamienna z XX-wiecznego snu może tu nasuwać na myśl grotę Narodzenia Pańskiego i łączyć się ze sceną Narodzenia Chrystusa ze snu XIX-wiecznego, podobnie mięso utopione we krwi we śnie Lubicz-Zaleskiego korespondować może z bardzo wyrazistą i charakterystyczną sceną „porodu wnętrzności” jako „porodu diabła” u Goszczyńskiego:

Sen dziwny, bardzo piękny. Widziałem całą scenę Narodzenia Chrystusa. Było to coś na kształt obrazu, ale żyjącego. Dziecię Chrystus leżało do mnie bokiem; z pościółki strzelały na wszystkie strony różnofarbne promienie jasności niezwykłej. Maria siedząca przy dziecku, twarzą do mnie, zatrudniona była poprawianiem czegoś przy dziecku, a lewą ręką przysłaniała sobie oczy przed jasnością dziecka, jak to robimy na przykład, patrząc pod słońce. (...) Podczas kiedy przypatrywałem się temu, uczułem wielką boleść w dolnej części brzucha i w tylnym otworze, po czym wyszła ze mnie nieczystość w postaci czarnego potworu, co mi stawiło zaraz na myśl diabła. Nie dojrzałem jej dobrze, a jednak wiedziałem, chociaż to się odbyło za mną i oczy miałem zwrócone w przeciwnym kierunku ${ }^{31}$.

Cóż, nie sposób nie zapytać w tych okolicznościach o skalę znajomości towianizmu, jaką mógł dysponować Zaleski. Sam Dziennik nieciagty - nie wprost - wskazywałby raczej na to, że była to wiedza zaawansowana, nie przyczynkarska. W Biesiadzie, a także Wielkim periodzie pouczał Towiański swojego czytelnika w sprawie tak zwanej religii chłopskiego tchnienia, co nieco później w sposób swobodny do własnych liryków genezyjskich przeniósł Słowacki (w tym do najstynniejszego, czyli Do pastereczki, siedzacej na druidów kamieniach $w$ Pornic nad oceanem ${ }^{32}$ ). Właśnie w interesującej nas tu drugiej połowie 1914 roku Lubicz-Zaleski zdaje się odwoływać do mistycznego uwielbienia ludu obecnego w systemie Towiańskiego. Świadectwem tegoż niech stanie się zapis z 22 września:

Myślę o tych ludziach prostych a czystych, ratuję zawsze mój optymizm niemal mistyczny, moją wiarę w człowieka, jeśli to nie brzmi zbyt pompatycznie... A gdy mi już specjalnie dokuczy towarzystwo wszystkich łajdaków i nicponiów małego i większego kalibru, to jedno spojrzenie w głębię duszy Janka Purwina uzdrawia

31 S. Goszczyński, 4 czerwca 1842 roku, sobota [w:] tegoż, Dziennik Sprawy Bożej, oprac., wstęp Z. Sudolski przy współpr. W. Kordaczuk, M.M. Matusiak, t. 1, Warszawa 1984, s. 24-25.

32 „I byłaś mi zarazem/ Chłopeczką - i Dyjanną,/ Zjawieniem i obrazem/ Kochanką i dziecięciem,/ Smutkiem - i niebowzięciem...”. J. Słowacki, Do pastereczki, siedzącej na druidów kamieniach w Pornic nad oceanem [w:] tegoż, Dzieła wybrane, dz. cyt., t. 1: Wiersze i poematy, Warszawa 2009, s. 70-71. W związku z tak zwaną religią chłopskiego tchnienia zob. między innymi Biesiadę Andrzeja Towiańskiego: „jakim jest więc orężem czystość, pokora, skrucha, kiedy jedno czyste westchnienie Pastuszka sprowadza Jemu światłą Kolumnę". A. Towiański, Biesiada [w:] tegoż, Biesiada. Wielki period, Kraków 2002, s. 10-11. 
mnie jak eliksir cudowny. A zresztą - dusze kobiece [podkr. moje: zaznaczam m.in. specyficzną frazę towianistyczną Lubicz-Zaleskiego - K.S.] $]^{33}$.

Snom profetycznym oraz widzeniom sennym towarzyszyły sny tryskające humorem, bez których cały przekrój dziennika snów i widzeń Lubicz-Zaleskiego pozostawałby zdecydowanie niepełny. Sny w funkcjach komicznych humoresek nadają tonu całości jako oniryczna przeciwwaga dla spotęgowanych widzeń wypełnionych genezyjskim katastrofizmem à la Juliusz Słowacki. 26 grudnia 1916 roku twórca późniejszego Relikwiarza buchenwaldzkiego śni w domu wariatów „egzamin z prorokowania”:

Sen trzeci, dzisiejszy: mam się dostać, czy nawet chcę dostać się do domu wariatów. Egzaminują mnie długo i w sposób męczący. Jeden z egzaminatorów utkwił mi w pamięci: czarny, smagły, o rysach wyrazistych (połączenie cech fizycznych [prof. Zygmunta - K.S.] Czernego i prof. Estreichera). Pyta mnie, czy prorokowałem kiedy ${ }^{34}$.

Warto zadać pytanie o możliwości dalszego badania tak głęboko uwewnętrznionej tradycji literackiej - nie tylko przecież ze względu na frapujący przypadek Zygmunta Lubicz-Zaleskiego. Sny pisarza nie manifestują, rzecz jasna, treści skonceptualizowanych, ujawniają się mimo wszystko w jakiejś dającej się oznaczać warstwie ekspresji oraz artykulacji. Zaryzykowałbym stwierdzenie, że manifestują swoją nacechowaną obecność interfiguralnie. Interfiguralność jest specyficzną odmianą intertekstualności. Autorstwo terminu, co więcej - stworzenie kompletnej teorii interfiguralności, przypisać należy Wolfgangowi G. Müllerowi. W swoim studium (fundamentalnym dla tematu) zatytułowanym Interfigurality: A Study on the Interdependence of Literary Figures stara się objaśnić naturę tak zwanych figur do ponownego wykorzystania ( $r e-$ -used figures). Jednocześnie dodaje: „termin "figury do ponownego wykorzystania« przedkładam ostatecznie ponad terminy »figury zapożyczonej« (figure

33 Z. Lubicz-Zaleski, Wtorek, 22 IX 1914 [w:] tegoż, Dziennik nieciagty (1904-1925), dz. cyt., s. 48.

${ }_{34}$ Tenże, 26 XII 1916 [w:] tegoż, Dziennik nieciagty (1904-1925), dz. cyt., s. 184. Należy raczej zanegować możliwość oddziaływania na Lubicz-Zaleskiego mody na freudyzm, gdyż takowej w Paryżu jeszcze nie było. Jak twierdzi Lena Magnone, Francja „była obok Niemiec krajem, w którym freudyzm napotykał najzacieklejszy opór”, co miało również związek z „powojenną germanofobią" mieszkańców Paryża. Ostatecznie dopiero „w kwietniu 1921 r. (...) na łamach periodyku ukazał się pierwszy artykuł poświęcony możliwościom wykorzystania narzędzi psychoanalitycznych do interpretacji dzieł literackich”, a „na początku 1922 r. Jules Romains, odnotowując salonową modę na psychoanalizę, przewidywał, że po fali fascynacji Einsteinem, "ta zima będzie, obawiam się, sezonem Freuda"”. L. Magnone, Eugenia Sokolnicka. Pionierka psychoanalizy we Francji [w:] tejże, Emisariusze Freuda. Transfer kulturowy psychoanalizy do polskich sfer inteligenckich przed druga wojna światowa, t. 2, Kraków 2016, s. 41, 48. 
on loan) oraz "wypożyczonej« (borrowed figure)”35. „Pełna, interfiguralna identyczność nie jest osiągalna", tłumaczy bowiem Müller:

Mówimy o figurach do ponownego wykorzystania po to, by wskazać, że jeśli autor przejmuje figurę z pracy innego autora do pracy własnej, wchłania ją w obręb formalnej i ideowej struktury własnego utworu, wykorzystując na własny użytek, który może obejmować zakresy od parodii i satyry aż po fundamentalne przewartościowania, a ostatecznie i ponowne odkrycie rozpatrywanej figury ${ }^{36}$.

\section{W obronie polskiej racji romantycznej}

Przybycie Lubicz-Zaleskiego do Paryża wywołać musi spore zamieszanie. Poza, którą początkowo przyjmuje Polak, jest w równym stopniu pozą młodego erudyty, jak amatora i pasjonata polskiej literatury. „Kiedyś śród tych gąszczy dwie godziny z furią i miłością objaśniałem Veronowej... Treny Kochanowskiego po francusku" ${ }^{37}$ - wspomina Zaleski we wpisie z 23 września 1914 roku. Punktem wyjścia jest jednakże dla niego zawsze polska racja romantyczna. To z jej perspektywy przeprowadza obronę sprawy polskiej, czy to w gronie paryskich rusofilów oraz slawistów, czy w publicznych debatach o jedności Słowiańszczyzny w Paryżu w tymże roku. 4 kwietnia 1916 roku zapisuje w Dzienniku:

Dzisiejszy odczyt E. Denisa o przyszłości Słowian utrwalił mnie jeszcze mocniej w przekonaniu co do stanowiska i charakteru p. Denisa. Warto zaznaczyć, że na kilkanaście nazwisk rosyjskich, kilka czeskich i serbskich - Denis, podobnie jak w sobotę Eisenmann, nie zacytował ani jednego polskiego (dla dokładności wspomniał raz... Puszkina i raz... Mickiewicza). Ta umyślna gołosłowność obok kilku mniej lub więcej zdawkowych komplementów, to także cecha charakterystyczna, gdy ci panowie mówią o Polsce ${ }^{38}$.

Nie wolno zapominać, że Lubicz-Zaleski, broniąc sprawy polskiej w tyglu ówczesnych debat o jedności słowiańskiej, także jako prezes Towarzystwa Artystów Polskich w Paryżu (został nim w 1916 roku), wypowiadał się - i miał tego

${ }^{35}$ G.W. Müller, Interfigurality: A Study on the Interdependence of Literary Figures [w:] Intertextuality, red. H.F. Plett, Berlin-New York 1991, s. 107.

36 Tamże.

37 Z. Lubicz-Zaleski, Środa, 23 IX 1914 [w:] tegoż, Dziennik nieciagty (1904-1925), dz. cyt., s. 49-50.

${ }^{38}$ Zaleski pisze tu także wprost o „arcysprytnych insynuacjach o niebezpieczeństwie pozostawienia Polski samej sobie, gdyż... »już o Sobieskim mówiono, że stworzył on potęgę niemiecką", służył Niemcom”. Tenże, Wtorek, 4 IV 1916 [w:] tegoż, Dziennik nieciagty (19041925), dz. cyt., s. 171. 
pełną świadomość - w imię określonej spuścizny, którą były otoczone nimbem popularności, a nawet legendy Wyktady o literaturze stowiańskiej Adama Mickiewicza. Spuścizna ta stanowiła zarazem w pewnym sensie jego własne prawo do zabrania głosu, a nawet prerogatywę. Mickiewiczowskich prelekcji paryskich dotyczyły paryskie wykłady Lubicz-Zaleskiego w latach 1914-1916. To on również był autorem uroczystego, jubileuszowego wykładu w stulecie Wyktadów o literaturze stowiańskiej w Montpellier w 1941 roku.

Z tej perspektywy Lubicz-Zaleski podejmował dyskusję z francuskimi historykami i słowianofilami, wpierw - z Paulem Boyerem, prezesem L'École des Langues Orientales, rusofilem i slawistą. Kontrowersja dotyczyć miała „antysemickiej” zajadłości Polaków i światopoglądowej rzekomo czystości Rosjan. Dialog rozpoczął się zaś od wynurzenia o Mickiewiczu jako „polskim Puszkinie":

W tym miejscu p. Boyer zaczął wyrzekać literalnie na Moskali. Potem jednak chwaląc wielkość naszej literatury, nie zaniedbał stwierdzić rażącego podobieństwa Mickiewicza i Puszkina. Zdumiony byłem mocno, alem nie oponował. Chwalił wreszcie liberalizm rosyjski, brak szowinizmu, brak antysemityzmu. W Polsce jest antysemityzm niejako urzędowy. W Polsce jest odpowiednik takiej Libre Parole [paryska gazeta antysemicka - K.S.]. W Rosji nie (!!!). Takie Nowoje Wremia rzekomo antysemickie - właściwie nie ma tego znaczenia. Zresztą żaden szanujący się Rosjanin nie szanuje Nowoje Wremi. Tu pozwoliłem sobie wtrącić pewnym nawet impetem: „łatwo być Rosjaninowi wolnym od racjonalizmu, szowinizmu i antysemityzmu, bo w tym względzie wyręcza go, i jak jeszcze skutecznie, rząd, biurokracja, państwo całe - system" 39 .

Wrażliwość Lubicz-Zaleskiego na stereotypy, zwłaszcza etniczne i narodowościowe związane z polskim romantyzmem, skutkowała jeśli nie dystansem, to zjadliwymi a błyskotliwymi replikami, także o nacechowaniu antysemickim. Co do działacza socjalistycznego, Stanisława Posnera (właściwie: Salomona Posnera), z którym pozostawał stale w 1914 oraz 1915 roku skłócony, tamten „wymyślał na Krasińskiego i przypominał o żydowskim pochodzeniu Mickiewicza” ${ }^{40}$.Dawnom Posnera nie widział - zatrącał o niewygodną kwestię Zaleski, a następnie śmiało przechodził dalej - nigdy jeszcze nie budził we mnie takiego wrogiego nastroju. Czuję w nim obcego - a to czasem więcej znaczy niż wróg”“11. „Pikantną” dyskusję-rozprawę z francuskim historykiem,

39 „Boyer patrzy nie tylko na Polskę, ale ponoć i na cały świat oczami inteligentnego liberała rosyjskiego". Z. Lubicz-Zaleski, Wtorek rano, 10 VIII 1915 [w:] tegoż, Dziennik nieciqgty (1904-1925), dz. cyt., s. 145.

40 Tenże, Poniedziatek, 14 VI 1915 [w:] tegoż, Dziennik nieciagty (1904-1925), dz. cyt., s. $132-133$.

41 Tamże, s. 133. 
Charles'em Seignobosem autor Dziennika nieciagtego sprawozdawał z kolei w krótkich, żołnierskich słowach w notatce z 5 stycznia 1916 roku:

Twierdzi on, że Polacy nie pozbyli się instynktów zaborczych. Na tym tle wywiązała się dyskusja o stosunku do Litwinów, Rusinów i Białorusinów. „Kościuszko - rzucił między innymi, to przecież nie Polak; to samo - dodał z wahaniem - Mickiewicz”. „Oczywiście - odrzuciłem - w tym sensie, w jakim wszyscy Prowansalczycy, Bretończycy i Baskowie nie są Francuzami”’22.

Równolegle do polskich fascynacji oraz polskiej erudycji literackiej uderzać musiała erudycja (wówczas trzydziestodwuletniego) Lubicz-Zaleskiego w obszarze romantycznej oraz modernistycznej literatury europejskiej. Szczególnie wobec snobizujących w Paryżu Polaków - piętnował ich niewiedzę i protekcjonalną zaściankowość w osądach. Po raz kolejny naturalnie - żarliwie spierał się z Posnerem. We wpisie z 3 listopada 1914 roku notował za polskim socjalistą - czym dawał widomy dowód co do tego, że jego projekt romantycznego intelektualizmu nie jest jedynie kolejnym „partykularyzmem”:

Dla powieściopisarza francuskiego - twierdzi Posner - wystarcza problem miłosny, a i to bez szacunku dla kobiety równej mężczyźnie, chociaż Francuz będzie przed kobietą klękał zgodnie z tradycją trubadurów. Jeden tylko Zola wprowadza tłum do powieści. Nie potrzebuję tu oczywiście przytaczać mojej repliki. Wspominam o Balzacu, o George Sand, Wiktorze Hugo, nawet Anatolu Fransie, Darre, Romain Rolland, Paulu Borget, ze wszystkich obozów, słowem, co najpierwszych ${ }^{43}$.

\section{Styl gawędowy}

Nie jest (oczywiście) wielką sztuką dostrzec, że styl pisarski w Dzienniku nieciagtym jest od przezroczystego jak najdalszy. Wspomniałem o naleciałościach pisarstwa genezyjskiego Słowackiego, a także - o niewykluczonym oddziaływaniu towianistycznego stylu dziennikowego Seweryna Goszczyńskiego. Czas zatem wspomnieć o stylu polskiej gawędy szlacheckiej - to nim (jak się zdaje) należy umotywować uderzająco podobny do stylu Trzy po trzy Aleksandra Fredry idiom narracji obecny we wpisie z 4 marca 1915 roku. Inspiracja Fredrą jest tu możliwa, chociaż pełne wydanie jego pamiętników (w odcinkach w „Gazecie Polskiej”) nastąpiło dopiero dwa lata później. Niemniej Lubicz-Zaleski mógł zetknąć się w młodzieńczych latach z 11. tomem dzieł Fredry

${ }^{42}$ Z. Lubicz-Zaleski, Środa, 5 I 1916 [w:] tegoż, Dziennik nieciagty (1904-1925), dz. cyt., s. 167.

${ }_{43}$ Tenże, Wtorek, 3 XI 1914 [w:] tegoż, Dziennik nieciagty (1904-1925), dz. cyt., s. 73. 
(zawierającym Trzy po trzy) opublikowanym nakładem warszawskiego wydawnictwa Gebethner i Wolff. Wszystkie tomy pojawiły się w druku w 1880 roku:

Miesiąc bez mała nie zaglądałem do Ciebie, mój dzienniku kochany! Miesiąc pełen ruchu, gwaru, wystąpień publicznych, ujadań, porażek i triumfów. Na horyzoncie dziejowym niewiele się zmieniło, przynajmniej dla nas. Tylko armaty w Dardanelach (armaty francusko-angielskie) wprowadzają do symfonii wojennej ton nowy ${ }^{44}$.

Styl gawędowy Lubicz-Zaleskiego rozwija się najsilniej symultanicznie do jego stylu profetyczno-onirycznego, to jest przede wszystkim w latach 19141915. Swadzie narracyjnej towarzyszyć mogą ekstremizmy semantyczne oraz leksykalne, tak jak we wpisie z 16 sierpnia 1915 roku z bardzo charakterystyczną frazą: „przy kolacji kataklizmowo wprost rozbolała mnie głowa”45. 14 czerwca 1915 roku Lubicz-Zaleski pisze już wręcz w odmianie neosarmackiej funambulesque, czym prowokuje uzasadnione skojarzenia ze stylem Jana Chryzostoma Paska/Henryka Rzewuskiego:

Pojechaliśmy razem do Antka Potockiego. Licho (a raczej zmęczenie, przy którym tracę zdolność moich dobrych odruchów intuicyjnych) skusiło mnie pójść na górę. Byłem tam potrzebny jak Piłat w kredo. Miałem po tym rozstaniu niesmak całe czterdzieści osiem godzin. Brr! Summa summarum nie podobałem się chyba zbytnio Zaglenicznemu i co gorsza... bez wzajemności. On bowiem zupełnie przypadł mi do gustu - jest zacny, miły, rozumny, dużo wie, nie jest ciasny i ma duszę rzetelną ${ }^{46}$.

Warto odwołać się do konkretnych, choćby przykładowych wyimków przywołanych powyżej intertekstów:

Teraz pozwól, szanowny obywatelu, zapytać się, czy stałeś kiedyś dzień cały w polu na wietrze zimowym bez delii, lisiurki albo i płaszcza? - Nie. - Tym lepiej dla ciebie, a gorzej dla mnie, bo nie pojmiesz dobroczynnego uczucia, z którym w Montereau, tysiąc óśmset czternastego po narodzeniu Jezusa Chrystusa, koło szóstej wieczór odpiąłem pałasz, zdjąłem mundur i zasiadłem, gdzie potężny ogień strzelał węglem i lizał płomieniem szerokie podniebienie komina ${ }^{47}$.

${ }_{44}$ Tenże, Czwartek, 4 III 1915 [w:] tegoż, Dziennik nieciagty (1904-1925), dz. cyt., s. 124.

45 „Głosy brzmiały tępo, słowa zapadały bez szelestu prawie, każde oddzielnie, niby gałki z papieru rzucane w watę”, a ostatecznie „cały ból ten oczywiście rodem z ucha” - kwituje dowcipnie całą sprawę (nie przestając przy tym stylizować) Zaleski. Tenże, Poniedziatek, 16 VIII 1915 [w:] tegoż, Dziennik nieciagty (1904-1925), dz. cyt., s. 146-147.

46 Tenże, Poniedziatek, 14 VI 1915 [w:] tegoż, Dziennik nieciagty (1904-1925), dz. cyt., s. 134 .

${ }^{47}$ A. Fredro, Trzy po trzy, oprac., wstęp K. Czajkowska, Warszawa 1977, s. 89. 
Razu jednego staliśmy obozem pod Jędrychowem, gdzie mieszkał JW. Ankwicz, kasztelan sandecki, pan godny i nam sprzyjający. Pan Bóg jego w synie nie pobłogosławił: on w ślady ojca nie wstępował; ale pokój umarłym. Otóż ten zasłużony senator starszyznę naszą zaprosił na wielki obiad, a dla nas niższych na dziedzińcu były zastawione jadła. Cieszyliśmy się wszyscy w Bogu; a na pokojach za siołem z panami siedział ksiądz Marek, o którym wiedział JW. kasztelan, co to był za człowiek ${ }^{48}$.

Miłościwy, Najjaśniejszy Królu, Panie a Panie mój Miłościwy! Taka wprawdzie jest ludzkiego reguła życia, żeby, jako cień za słońcem, tak nieszczęścia za szczęściem następowała alternata, żeby złego z dobrym, kłopotów i frasunków z pomyślnościami ustawiczna człowieka inkwijetowała vicissitudo (...). Ale przecie kiedy komu złym za dobrem, niewdzięcznością nagradza się za wdzięczność, (...) jest to afflictio supra afflictiones, dolegliwość nad wszystkie dolegliwości ${ }^{49}$.

\section{Romantyczna młodość}

Już dotychczasowa próbka cytatów z Dziennika nieciągtego wystarcza, ażeby stwierdzić, że biografia Lubicz-Zaleskiego, a zwłaszcza będący tematem Dziennika okres jego formacji światopoglądowej między dwudziestym a czterdziestym rokiem życia, stanowi odpowiedzialną próbę „romantycznej całości”. Siłą rzeczy, kluczem do owej „całości” muszą pozostać inicjacje młodości. Utrzymają one swoją aktualność także w mrocznym okresie „od Grotowic do Buchenwaldu”. W Limoges 29 listopada 1940 roku, jak spostrzega się Zaleski, „chmury dziergane słońcem... przesuwają się jak w ostatniej operowej scenie Potępienia Fausta" ${ }^{50}$. Dwa dni wcześniej w Tuluzie, w której mężczyzna wygłaszał wykład terenowy na temat Przedświtu Krasińskiego, krótko po własnym odczycie niewykluczone, że pod wpływem przeżyć wykładowych i Krasińskiego - wpada w rodzaj gniewnej egzaltacji we wnętrzu Katedry Świętego Szczepana: „patrząc w głąb dwoistą katedry, wpadam w wewnętrzną wściekłość, która zapala istną pożogę krwi pod kopułą błękitnego rozmarzenia" ${ }^{51}$.

Frenetyczne uniesienia dojrzałego Zaleskiego z Tuluzy i z Limoges to spuścizna jego romantycznej młodości. W Dzienniku nieciagtym pierwsze zapisy snów, widzeń, fantazji, a także improwizacji wyobraźniowych przynosi już rok

${ }^{48}$ H. Rzewuski, Ksiądz Marek [w:] tegoż, Pamiątki Soplicy, oprac. Z. Szweykowski, Wroctaw 2004, s. 288.

49 J.Ch. Pasek, Pamiętniki, z rękopisu wydał, wstęp, oprac. J. Czubek, Kraków 1929, s. 240.

50 Z. Lubicz-Zaleski, Limoges, 29 XI 1940 [w:] tegoż, Pamiętnik. Od Grotowic do Buchenwaldu (1939-1945), dz. cyt., s. 104.

${ }^{51}$ Tenże, Tuluza, 27 XI 1940 [w:] tegoż, Pamiętnik. Od Grotowic do Buchenwaldu (19391945), dz. cyt., s. 104. 
1904. Dwudziestodwuletni młody Polak - podobnie jak ten pięćdziesięcioośmioletni pod wpływem muzyki Hectora Berlioza - fantazjuje zaraz po wysłuchaniu Czajkowskiego. Lubicz-Zaleski notuje we wpisie z 23 lipca:

Słuchałem dziś Manfreda Czajkowskiego [na motywach dramatu George’a Gordona Byrona - K.S.]. Widziałem bohatera zjawiającego się poprzez rozhuk popękanych lodów, hen na iglicach niedostępnych szczytów w obłoku perlistego pyłu wody tryskającego z głębin Nieznanego. Z tym skojarzył się jakiś fragment przedstawiający żyrondystów prowadzonych na szafot. Miałem widzenie największego bohatera Irlandii (Roberta Emmeta) podczas ostatniej mowy w sądzie skazującym go na śmierćs2.

To przedziwne, a zarazem wiele mówiące, wzniosłe i makabryczne wyliczenie: lód, wodospady, szafot i Robert Emmet w trakcie słynnej, ostatniej przemowy, bardzo swoistej, irlandzkiej „obrony Sokratesa”. Lubicz-Zaleski słucha oraz kontempluje Czajkowskiego w określonych - budowanych przez siebie jako „projekcje” - cywilizacyjno-kulturowych całościach. Wszystko powtarza się 29 października 1904 roku, gdy wysłuchuje Symfonii patetycznej. W jego synestezyjnym odbiorze arcydzieła Czajkowskiego dają się usłyszeć echa niewątpliwie poruszającej go w sposób maksymalny lektury Króla-Ducha Słowackiego:

Byłem na Symfonii Patetycznej Czajkowskiego. Część I - wielkie zmaganie się ducha rozpotężnione purupurowo lśniącą falą dalekich odsłonień miłosnego zachwytu, II - przyjemny, umiarkowanie słodki i upojny walc. III - jeślim widział kiedy człowieka, który całe wielkie Jutro wymienił na opętańcze, rozpasane Dziś - to tu odnalazłem go całkowicie. Część I obrazowałem sobie jako wchodzenie bohatera na szczyt, tam wznosi on świątynię z cyklopowych głazów, ale oto przychodzi wielki duch zniszczenia, słychać walenie się murów i rozhuk zataczających kręgi głazów. Dom Boży runął. Co zrobi wtedy budowniczy? Frunie także? Czy może zatraci się na chwilę życia w melancholijnym wirze półnagich, gibkich ciał? Prawda posiekana na kawałki i właśnie do oddziaływania przyrodniczego ${ }^{53}$.

Jeżeli wolno się tak wyrazić - właśnie w długim cieniu Króla-Ducha Lubicz-Zaleski przeżywać będzie zbliżające się strajki studenckie 1905 roku. W tym samym wpisie sporządzanym poza Warszawą, w Bałdowie, 14 lipca 1905 roku utalentowany student wyliczy swe „prowincjonalne” lektury: między innymi Sztukę i krytykę Stanisława Witkiewicza, a także Zagrzebana światynię Maurice'a Maeterlincka z 1902 roku. Tę drugą, co godne uwagi, czytać będzie w oryginale w trzy lata po wydaniu we Francji, zaraz po napisaniu jedynego własnego

52 Tenże, Sobota, 23 VII 1904, godzina 12 [w:] tegoż, Dziennik nieciagty (1904-1925), dz. cyt., s. 19.

53 Tenże, 29 X 1904 [w:] tegoż, Dziennik nieciagty (1904-1925), dz. cyt., s. 25-26. 
dramatu $Z$ życia studentów warszawskich ${ }^{54}$. Powrócę jednak do strajków. Studentom z roku 1905 Lubicz-Zaleski zarzucać będzie tchórzostwo oraz genezyjskie (z ducha Słowackiego) zaleniwienie, a zatem - mówiąc najkrócej - niegotowość do symbolicznych choćby ofiar w imię narodowej konieczności dziejowej. Wyzna bez półsłówek, niemalże cynicznie:

Ulżyłem sobie, widząc, jaka bezmierna tępota wieje od nich. Jeśli nie powiedzie nas bicz konieczności - ów nasz Król-Duch odwieczny - nie pójdziemy własną wolą nie! Bez szemrania pozwoliliśmy wydrzeć sobie czterdzieści tysięcy par rąk, które na polach Mandżurii na zawsze stracone zostały dla polskiej ziemi, ale rok zawieszenia pracy w szkole obcej dla zdobycia własnej jest zbyt wielkim ciężarem - nie ma kto smagać ramion naszych, aby go poniosły ${ }^{55}$.

Jak już wskazywałem, Dziennik nieciagty w sposób bardzo konkretny może zdradzać odwołania do twórczości Norwida, zwłaszcza - do Promethidiona. Poetę Lubicz-Zaleski poznaje wówczas zapewne przez samego Zenona Przesmyckiego, Miriama, w okresie świetności „Chimery”, której wiernym czytelnikiem (najprawdopodobniej) pozostaje przez lata. We wpisie z 30 września 1904 roku Lubicz-Zaleski z odpowiednią celebrą informuje:

Dziś miałem prawdziwą uroczystość: Miriam powiedział mi, że mam talent. „Niewątpliwie ma Pan duży talent - oto słowa, którymi mnie przywitał. Jak rozświergotane jaskółki, dźwięczą mi one w uszach. Cechą moją dodatnią ma być kolorowość, ujemną zaś - nadużywanie alegorii. Również mam się strzec stylu biblijnego i w ogóle wszelkich stylów, aby nie zatracić, a raczej chyba zdobyć własny ${ }^{56}$.

Jeden z pierwszych odkrywców Norwida oraz późniejszy założyciel i dyrektor jedynego wolnego liceum polskiego na terenie okupowanej Europy ${ }^{57}$

${ }^{54}$ Tenże, Batdów, 14 VII 1905 [w:] tegoż, Dziennik nieciagty (1904-1925), dz. cyt., s. 28. Młodzieńczy portret Lubicz-Zaleskiego jest portretem trwale niedopełnionym (nie mówiąc o tym, że niepoznanym). Tu wyłania się obraz niezwykle swoisty - mężczyzny jako niespełnionego, a niezwykle oczytanego i (co najistotniejsze) nadążającego za „modernistycznymi nowościami” dramaturga in spe. Zob. w związku z tym: M. Willaume, Wstęp, dz. cyt., s. 5-16.

55 Z. Lubicz-Zaleski, Batdów, 14 VII 1905, dz. cyt., s. 28.

56 Tenże, Piątek, 30 IX 1904 [w:] tegoż, Dziennik nieciagty (1904-1925), dz. cyt., s. 24. Dystans między Miriamem a Zaleskim rodzi się wraz z dyskusjami o zgubnie „rozpolitykowanych” studentach: „pozytywna strona działalności studenckiej winna polegać na wyrabianiu ludzi przez... koleżeńskość w stosunkach osobistych” - stwierdza Miriam. „Wygodne... i ultraszablonowe" - kwituje młody Zaleski. Tenże, 11 X 1904 [w:] tegoż, Dziennik nieciagty (1904-1925), dz. cyt., s. 24-25.

${ }^{57}$ Liceum polskie im. Cypriana Norwida powstało w październiku 1940 roku, nauczyciele natychmiast przystąpili do pracy. 24 października Lubicz-Zaleski notował: „Jeszcze jedna scena mojego teatru. Siedzę w klasie (II licealnej), uczniowie i uczennice piszą ćwiczenie... Muszę przekonywać siebie, że to rzeczywistość, nie senne przywidzenie... Tak, to rzeczywistość.. Jestem 
w drugiej części 1904 roku prowadzili regularne wspólne dysputy, które Lubicz-Zaleski przyzwyczaił się nazywać „konferencjami” ${ }^{8}$. $\mathrm{Na}$ „konferencjach” Miriam podsuwał swemu uczniowi tłumaczenia z języka francuskiego „dla wyćwiczenia języka" 59 - tak stało się między innymi 10 grudnia. Należy jednak zaznaczyć, że Norwid zdawał się znany Zaleskiemu jeszcze przed wrześniowym spotkaniem z Miriamem (co do którego jednak nie możemy być pewni, że było pierwsze). Niezwykle wymowny pod tym względem, a zarazem nadzwyczaj erudycyjny oraz przenikliwy pozostaje wpis o „manekinowości” świata, pozostawiony w Dzienniku nieciagtym pod datą letnią -28 lipca 1904 roku:

Oryginalne wrażenie zrobił na mnie przeczytany wczoraj Heinricha von Kleista O teatrze marionetek, w którym autor w sposób nieco norwidowski obrazuje tezę następującą: tracąc nieświadomość, utraciliśmy zarazem raj wdzięku i niewinności, możemy jednak uzyskać utracone, wchodząc do raju „od tyłu”, poprzez absolutną świadomość. Według słów autora, niewinność i wdzięk posiadać może tylko Bóg lub... manekin [podkr. - K.S. ${ }^{60}$.

Nie jest moim celem wskazywanie ani tym bardziej - dywagowanie na temat tego, czy Zaleski w autorskiej lekturze Kleista wyprzedził swój czas. Jego zapis z pewnością zdradza wiele nowoczesnych rejonów zainteresowań. Można chyba raczej bez większego ryzyka wnioskować, że zna Marionetki Norwida, a zatem czyta już wtedy „Chimerę”. „Sugeruje” on poniekąa także „śmiałą” komparatystykę - zestawiając Norwida z Kleistem. Zaś jego pozornie anachroniczna fascynacja

dyrektorem tego górskiego gimnazjum-liceum Cypriana Norwida... i uczę w klasie najwyższej literatury. Uroczystość otwarcia liceum odbyła się osiemnastego, prawie tydzień temu. Przemawiał mer Villard-de-Lans. Dygat Zygmunt zagrał na zakończenie z niemałą brawurą etiudę, dwa mazurki i Poloneza As-dur Szopena. Podobno wszystko odbyło się dobrze i sprawnie, i ja tak myślę". Tenże, Villard-de-Lans, 24 X 1940 [w:] tegoż, Pamiętnik. Od Grotowic do Buchenwaldu (1939-1945), dz. cyt., s. 97. Nie sposób ustalić na podstawie samego tylko pamiętnika Lubicz-Zaleskiego, jak w jego klasie wyglądała lekcja historii literatury. Wiemy jednak, że na inaugurację samorządu uczniowskiego uczniowie mieli wyrecytować Jana Kochanowskiego, Mikołaja Sępa-Szarzyńskiego, Szymona Zimorowicza, Szymona Szymonowicza, Wacława Potockiego, Jana Andrzeja Morsztyna, Ignacego Krasickiego, Stanisława Trembeckiego i Adama Mickiewicza. Tenże, Vichy, 11 XII 1940 [w:] tegoż, Pamiętnik. Od Grotowic do Buchenwaldu (1939-1945), dz. cyt., s. 105.

58 „Dziś miałem ciekawą konferencję z Miriamem”. Tenże, 25 XI 1904 [w:] tegoż, Dziennik nieciagty (1904-1925), dz. cyt., s. 26.

59 Tenże, 10 XII 1904 [w:] tegoż, Dziennik nieciagty (1904-1925), dz. cyt., s. 27.

${ }^{60}$ Tenże, 28 VII 1904 [w:] tegoż, Dziennik nieciagty (1904-1925), dz. cyt., s. 20. Pisze o tym wpisie dziennikowym Jan Zieliński, przypominając rozmowy Lubicz-Zaleskiego o Norwidzie ze współwięźniami Buchenwaldu, do którego poeta i działacz został zesłany na skutek ujawnienia jego działań w Villard-de-Lans. J. Zieliński, Postowie [w:] Z. Lubicz-Zaleski, Relikwiarz..., dz. cyt., s. 61-62. Zieliński zauważa również u Lubicz-Zaleskiego kopiowanie bardzo konkretnych technik obrazowania poetyckiego Norwida: między innymi zestawia wiersz tego pierwszego, Don Quijot w Buchenwaldzie z Norwidowskim wierszem Toast. J. Zieliński, dz. cyt., s. 55. 
Kleistowskim teatrem marionetkowym przypomina podobne fascynacje dramaturgów modernistycznych, a zestawienie Boga i manekina ze sobą, implicite więc dowodzenie „boskości” marionetki, to już niemal teza Edwarda Gordona Craiga z eseju Aktor i nadmarioneta, teza - można założyć ryzykownie - „przeczuwana” przez Lubicz-Zaleskiego, gdyż Craig ogłosi ją dopiero w 1907 roku.

W Aktorze i nadmarionecie geneza aktorstwa wiąże się z triumfem kobiecej słabości. Przypomnijmy, że Craig wywodzi „obłęd aktorski” z Dalekiego Wschodu z historii dwóch kobiet, które postanowiły zdetronizować marionetkę swoją nerwową pseudogrą kopiującą wykończone ruchy lalki, ,jaśniejące ziemską chwałą i nieziemską prostotą":

Chwasty, jak mówią, plenią się szybko, toteż wkrótce rozprzestrzeniło się to dzikie pole zielska, czyli nowoczesny teatr. Figura boskiej marionetki przyciagała coraz mniej wielbicieli, ostatnim krzykiem mody stały się owe dwie kobiety. Wraz ze zmierzchem marionetki i powodzeniem tych dwóch kobiet, które zamiast niej ukazywały się na scenie, nadszedł czas bardziej posępny, zwany Chaosem, a w jego świecie zatriumfowała hałaśliwa indywidualność. Czy teraz rozumiecie, dlaczego pokochałem i nauczyłem się cenić tę tak zwaną dzisiaj marionetkę i dlaczego znienawidziłem tak zwane „życie” w sztuce? ${ }^{61}$

\section{Zakończenie}

Tego rodzaju „przeczucia” (obawiam się zdecydowanego określenia: „antycypacje") stawiają Lubicz-Zaleskiego w pozycji trudnej do klasyfikacji, rozpiętego pomiędzy pozornie sprzecznymi intelektualizmami romantyzmu, neoromantyzmu oraz modernizmu. Miriamowskie wychowanie w cieniu rewolucji 1905 roku, wyrafinowane, ale krzyżujące ze sobą wiele porządków estetycznych lektury: w tym pierwszy przykład z brzegu - Kleist czytany Maeterlinckiem, Maeterlinck czytany Kleistem. Dziennik nieciagty wreszcie stanowi przykład $\mathrm{z}$ jednej strony dziennika postawy obywatelskiej emisariusza polskiej kultury romantycznej, z drugiej zaś frenetycznego dziennika snów i widzeń godnych "późnego wnuka” towiańczyków oraz Słowackiego genezyjskiego (a nie wolno tu zapomnieć o snach katastroficznych Zaleskiego obecnych zwłaszcza w pierwszych miesiącach wojny 1914 roku). Wszystko to konsekwentnie buduje „kameleonowość" doświadczenia estetycznego Lubicz-Zaleskiego.

W pierwszym odruchu słusznie zatem chciałoby się zakwestionować modernistyczny nimb Dziennika nieciagtego i stwierdzić zdroworozsądkowo nie ma takiego, a więc nie warto kreować iluzji. Jeszcze w Stowie od autora

${ }^{61}$ E.G. Craig, Aktor i nadmarioneta [w:] tegoż, O sztuce teatru, wyb. G. Sinko, tłum. M. Skibniewska, wstęp i noty Z. Hübner, Warszawa 1985, s. 71, 84, 91-92. 
Lubicz-Zaleski nie miał żadnego problemu ze spostponowaniem proustyzmu oraz wprowadzeniem na jego miejsce (a było to niemal ewidentne) przestarzałego patronatu russoistycznego. Autor Dziennika nieciagtego, na zmianę posługując się stylem publicznym, profetycznym, intelektualnym i gawędowym à la Pasek czy Rzewuski, nie wydaje się także dobrym kandydatem do badań stylometrycznych - ilościowych czy jakościowych. Jakże mógłby więc być modernistą jest spóźnionym, romantycznym intelektualistą, jednakże o niepowtarzalnym i niepodrabialnym idiomie estetycznym.

To idiom wiedzy i doświadczenia, w którym estetyczna epifania miesza się z akademizmem, w sposób naturalny tworząc - właśnie na wzór matryc modernistycznego poznania - spójną koegzystencję dwóch porządków. Nie będzie to widoczne w planie biografii Zygmunta Lubicz-Zaleskiego ani na tle jego twórczości literackiej. Fundamentalną (chociaż niełatwą do skonceptualizowania) wiedzę o tym, skąd, a więc z jakiej intelektualnej ojczyzny, przychodzi Lubicz-Zaleski, obywatel jednej ojczyzny, ale wielu estetyk, pozyskać możemy wyłącznie z jednego źródła. Jest nim Dziennik nieciagty, ukazujący wymiar biograficznej relacji personalnej, zapisywany w formotwórczym okresie 1904-1925, latach najwyrazistszej chyba artykulacji światopoglądowej - między dwudziestym drugim a czterdziestym trzecim rokiem życia autora, Polaka we Francji.

\section{Bibliografia}

Craig E.G., Aktor i nadmarioneta [w:] tegoż, O sztuce teatru, wyb. G. Sinko, tłum. M. Skibniewska, wstęp i noty Z. Hübner, Warszawa 1985.

Dą̧browicz E., Poeta-anonim, „Sztuka Edycji” 2012, nr 3.

Fredro A., Trzy po trzy, oprac., wstęp K. Czajkowska, Warszawa 1977.

Goszczyński S., 4 czerwca 1842 roku, sobota [w:] tegoż, Dziennik Sprawy Bożej, oprac., wstęp Z. Sudolski przy współpr. W. Kordaczuk, M.M. Matusiak, t. 1, Warszawa 1984.

Kostkiewiczowa T., „Wiersze późne” jako kategoria historycznoliteracka (zarys problemu) [w:] Wobec romantyzmu. Studia i szkice ofiarowane Profesor Danucie Zamacińskiej-Paluchowskiej, red. M. Łukaszuk, M. Maciejewski, Lublin 2006.

Krasiński Z., Pokusa [w:] tegoż, Dzieta zebrane. Nowe wydanie, red. M. Strzyżewski, t. 6: Proza poetycka III, Toruń 2017.

Krasiński Z., Przedświt [w:] tegoż, Dzieta zebrane. Nowe wydanie, red. M. Strzyżewski, t. 2: Poematy, Toruń 2017.

Lubicz-Zaleski Z., Dziennik nieciagty (1904-1925), oprac., przyp. M. Willaume, Paryż-Łódź 1998.

Lubicz-Zaleski Z., Od autora [w:] tegoż, Dziennik nieciagty (1904-1925), oprac., i przyp.M. Willaume, Paryż-Łódź 1998.

Lubicz-Zaleski Z., Pamiętnik. Od Grotowic do Buchenwaldu (1939-1945), oprac., przyp. M. Willaume, Paryż-Łódź 1998. 
Lubicz-Zaleski Z., Relikwiarz buchenwaldzki, oprac., posł. J. Zieliński, Warszawa 2016.

Lubicz-Zaleski Z., Zygmunt Krasinsski. $O$ dziele $i \dot{z y c i u}$ poety $w$ setna rocznice urodzin, Warszawa 1912.

Magnone L., Eugenia Sokolnicka. Pionierka psychoanalizy we Francji [w:] tejże, Emisariusze Freuda. Transfer kulturowy psychoanalizy do polskich sfer inteligenckich przed druga wojnq światowa, t. 2, Kraków 2016.

Mickiewicz A., Śnita się zima [w:] tegoż, Dzieta, red. J. Krzyżanowski, t. 1: Wiersze, Warszawa 1955.

Müller G.W., Interfigurality: A Study on the Interdependence of Literary Figures [w:] Intertextuality, red. H.F. Plett, Berlin-New York 1991.

Norwid C., Promethidion. Rzecz $w$ dwóch dialogach z epilogiem [w:] tegoż, Pisma wszystkie, zebrał, tekst ustalił, wstęp i uwagi krytyczne J.W. Gomulicki, t. 3: Poematy, Warszawa 1971.

Notre école. Mémoires du lycée polonais Cyprian Norwid 1940-1946, Villard-de-Lans 2017.

Pasek J.Ch., Pamiętniki, z rękopisu wydał, wstęp, oprac. J. Czubek, Kraków 1929.

Rousseau J.J., Wyznania, wstęp, oprac. E. Rzadkowska, tłum. T. Żeleński (Boy), Wrocław 1978.

Rzewuski H., Ksiądz Marek [w:] tegoż, Pamiątki Soplicy, oprac. Z. Szweykowski, Wrocław 2004.

Sacha M.I., Skrawki, notatki, drobiazgi, relikwie. O poezji buchenwaldzkiej Zygmunta Lubicz-Zaleskiego, „Acta Universitatis Lodziensis. Folia Litteraria Polonica” 2018, nr 1.

Słowacki J., Do pastereczki, siedzącej na druidów kamieniach w Pornic nad oceanem [w:] tegoż, Dzieta wybrane, wyb., przedm. M. Bizan, P. Hertz, t. 1: Wiersze i poematy, Warszawa 2009.

Słowacki J., Genezis z Ducha. Modlitwa [w:] tegoż, Dzieta wybrane, wyb., przedm. M. Bizan, P. Hertz, t. 1: Wiersze i poematy, Warszawa 2009.

Słowacki J., Ksiądz Marek. Poema dramatyczne we trzech aktach [w:] tegoż, Dzieta wybrane, wyb., przedm. M. Bizan, P. Hertz, t. 3: Dramaty, część druga, Warszawa 2009.

Słowacki J., Sen srebrny Salomei. Romans dramatyczny w pięciu aktach [w:] tegoż, Dzieta wybrane, wyb., przedm. M. Bizan, P. Hertz, t. 3: Dramaty, część druga, Warszawa 2009.

Talko L., Przedmowa [w:] Z. Lubicz-Zaleski, Dziennik nieciagty (1904-1925), oprac., przyp. M. Willaume, Paryż-Łódź 1998.

Towiański A., Biesiada [w:] tegoż, Biesiada. Wielki period, Kraków 2002.

Willaume M., Wstęp [w:] Z. Lubicz-Zaleski, Dziennik nieciagty (1904-1925), oprac., przyp. M. Willaume, Paryż-Łódź 1998.

$Z$ dala od orkiestry, reż. R. Lewandowski, Polska 2017, 86 minut.

Zieliński J., Postowie [w:] Z. Lubicz-Zaleski, Relikwiarz buchenwaldzki, oprac., posł. J. Zieliński, Warszawa 2016. 